\title{
THE VALUE OF IT CERTIFICATION: PERSPECTIVES FROM STUDENTS AND IT PERSONNEL
}

\author{
Mohammad A. Rob, University of Houston-Clear Lake, rob@uhcl.edu \\ Auklesh Roy, University of Houston-Clear Lake, auklesh@gmail.com
}

\begin{abstract}
The value of IT certification has been a subject of debate for the past decade. Research suggests that IT certification can boost fresh graduates' profile to get attention of the hiring manager. IT magazines suggest that certifications can bring opportunities for existing employees with better positions, promotion and salary increase. For years, educators have been suggesting to include IT certifications in traditional computing curricula of higher education. However, due to lack of knowledge and commitment, faculty members have been reluctant to include IT certification in traditional degree programs. In this paper, we report the results of integration of several IT certifications in a graduate MIS program of a U.S. university. It is found that almost all current or past students believe that IT certification can help them build a better career. Certifications from Oracle, Microsoft and Cisco are found to be most valuable to them. We recommend that educationists who are faced with the dilemma of whether or not to adapt IT certifications in their computing curricula, should take the positive steps. That will bring IT departments up to the par of IT industry standards.
\end{abstract}

Keywords: IT Certification, IS Curriculum, IT Employment, IT Skills, University Curriculum

\section{INTRODUCTION}

Over the past decade, there has been a significant growth and attention to IT Certifications. IT magazines such as Computerworld, Certification, and NetworkWorld have been suggesting that IT certifications boost a candidate's profile to land a job, promotion or salary increase [3, 4, 8]. Research suggest that getting certified is the best way to distinguish oneself from competing job candidates and prove the attainment of contemporary skills to hiring managers and prospective employers [12, 26, 30]. Attainment of IT certification makes one stand apart, proves that skills are current, and provides higher salaries as well as gives respect and credibility among colleagues and employers. On the other hand, research on IT job postings suggests that only a small fraction of the advertised jobs require IT certification [15, 23, 26,]. For many years, educationists have been suggesting to integrate IT certifications into traditional computing curricula in colleges and universities [20, 27, 28]. Many junior colleges are offering courses that prepare students to appear for IT certification exams [20, 27, 28]. However, it is not clear how many colleges or universities have integrated IT certifications into their degree programs. The MIS program at the University of Houston-Clear Lake (UHCL) has integrated IT certifications in several of its graduate core courses. This paper briefly discusses the steps of integration, issues encountered by the faculty members, and the results of integration from the viewpoints of past and present students.

\section{DEMAND OF IT CERTIFICATION}

Many IT graduates are finding that in addition to a degree, they need experience - which cannot be achieved by fresh graduates. Also, there is a common belief that having an IT certification can boost a new graduate's chances to get an HR manager's attention [12, 26,30]. Many government agencies now require personnel who handle sensitive information to hold one or more IT certifications [16]. According to a recent report published in NetworkWorld magazine, a survey of 700 network professionals found that $60 \%$ landed a new job and $50 \%$ earned more with IT certifications [4]. According to an article in Certification magazine, professionals who get certified feel secure in their profession [8]. According to a salary survey based on the Microsoft certifications, 71 percent said that obtaining certification was a personal goal, while 48 percent said certification would help them distinguish their skills from others, and 32 percent said it worked as a leverage to get a better job [18]. 


\section{Issues in Information Systems}

Volume 14, Issue 1, pp.153-161, 2013

There have been some serious discussions in the literature regarding the value of IT certification in the hiring practices of IT professionals. Eighty-six percent of hiring managers indicate that IT certification is a medium to high priority during a candidate's evaluation process [7]. Ninety-one percent of hiring managers say that certification is a part of their hiring criteria [19]. Hunsinger and Smith [12] investigated the factors that influence a given hiring manager's intention to use IT certification as part of employee selection. Their findings show that managers sometimes use certification to differentiate between job candidates with similar levels of education and experience. Anderson, Barrett and Schwager [2] surveyed HR managers and found that IT certification, formal education and experience are imperfect substitutes for each other. Wierschen and Zhang [30] also looked at the value of certification from the employer's perspective in academic institutions, and it is found that academic IT departments do value IT certification, and they either require IT certification or expect employees to be working towards certification; however, an overwhelming endorsement of IT certification was not evident.

Lee and Lee [15] analyzed job postings for IT Managerial position over a period of three years, and they concluded that only $7.7 \%$ of advertisements mentioned IT project management certification as a plus in addition to education and experience. Robin [26] studied job vacancies and analyzed in terms of education, experience and IT certification requirements. The results show that 70 percent require a bachelor degree, 85 require experience, and about 14 percent require some sort of certification.

It is clear from the literature that IT certification is not a significant factor in the hiring practices, but it gives an edge in the job prospect for fresh graduates, and it provides a significant salary benefit or promotion or better position to existing professionals. However, Certification establishes a standard of competency in specific areas and job roles [1]. It helps IT industry to determine that employees meet the required credentials for different jobs roles; requiring less training during the initial employment period. To the individual, certification provides a greater sense of confidence in their abilities and a measure of professional expertise and understanding of the job role and products used in that role. It is for these reasons that certification is becoming increasingly popular and in high demand [1].

\section{IT CERTIFICATION AND ACADEMIC CURRICULUM}

This is the most discussed and debated area found in the literature. Schlichting and Mason [27] argues that the academicians in computing programs tend to reject the path followed by IT industry, and even refuse to consider offering courses that prepare students for certification exams. Certification training is considered as "trade-school" work that is below the dignity of a rigorous academic curriculum. In a follow-up paper, Schlichting and Mason [28] mentions that academicians within the computing area are of a mixed mind when it comes to certification training. Although they generally believe that certification enhances students' employability, at the same time, they do not consider preparation for these tests to be the responsibility of computer departments. Randall and Zirkle [25] looked into various issues surrounding the use of IT certification in formal education setting. They mention that unlike community colleges, four year post-secondary institutions have been slow to offer students added benefit of pursuing an IT certification as a compliment to their degrees. Hunsinger and Smith [13] surveyed information system undergraduates to understand the factors that can influence them to pursue IT certification. They found that a lack of knowledge about certification and the faculty role to inform students about the value of certification and related course content are major factors of change.

Nelson and Rice [20] justified the need and value of IT certification along with the educational degree, and reported the integration of seven certifications in various courses in the associate and bachelor level IT curricula of a small college. The two most popular certifications were focused on office productivity software and operating systems. While implementation of certifications at the associate level seemed to be successful, the more ambitious certifications at the bachelor level that required many exams were not as successful. Ortiz [22] describes an experience in developing a workshop specifically designed to prepare undergraduate students to take Sun Java certification exam. It is concluded that there are challenges in offering certification preparation course in a regular 


\section{Issues in Information Systems}

Volume 14, Issue 1, pp.153-161, 2013

university class environment; however, the course provided a deeper understanding of Java language to students, which wouldn't happen otherwise. Jonanovic et. al [14] outlined possible ways of implementing multiple certifications programs in an Australian university. Frank and Werner [9] outline the experience of preparing, taking and obtaining CSSLP certification by one of the authors who teaches software engineering-related courses. It is concluded that preparing for and taking a certification exam can improve an educator's expertise and ability to successfully teach a course; however, the authors remain skeptical about the inclusion of IT certifications in the traditional IT curriculum.

While the debate of including IT certification in the academic curriculum continues, we report in this paper the results of integration of several IT certifications into our master's-level MIS curriculum. But first we provide an overview of IT certifications as we have learned while going through the process of integration over a period of about six years. It will be a valuable asset to those who may consider adapting similar certifications into their curricula.

\section{AN OVERVIEW OF IT CERTIFICATION}

Keeping up with the IT certification industry has been a challenge. It is constantly changing due to change of technology in almost every two years. It is also seen as a tool to generate new money for IT companies and its related training and publication industry [11]. GoCertify.com provides an alphabetic listing of hundreds of vendors offering IT certifications which include big technology names such as Apple, Cisco, Google, HP, IBM, IEEE, Linux, Oracle, McAfee, Microsoft, Nortel, Novell, PayPal, PMI, SAP, SAS, SEI, Teradata and etc. [10]. According to Hitchcock [11], in 2000 there were about 300 IT certifications and 1.6 million people holding approximately 2.4 million certifications. No current information could be found, but according to Hunsinger and Smith [12], the number of people holding IT certifications might have reached 20 million by 2010 .

IT certifications can be divided into two general groups: vendor-specific and vendor-neutral. Certifications related to products and services of technological companies such as Microsoft, Cisco, Oracle, and Novell are in the first group, and those related to IT professions such as project management, security, and business intelligence offered by independent organization such as CompTIA, (ISC) ${ }^{2}$, PMI, and SEI are in the second group. Most vendor certifications are divided into various hierarchical levels. For example, Cisco certificates are organized into five levels: Entry, Associate, Professional, Expert, and Architect along with targeted certifications for Specialist and Technician. Oracle offers three levels of certification, Oracle Certified Associate (OCA), Oracle Certified Professional (OCP), and Oracle Certified Master (OCM) in several disciplines such as database, application server, forms, PL/SQL, e-Business, and so on that include several hundred tests [21]. The newly revamped Microsoft Office certification path has five levels: Specialist, Expert, Master, Technology Specialist and Technology Professional [17]. Typically one starts from the lower level and climbs upward by completing next-level certification. In most cases, each certification level requires multiple exams to take, and all certifications are valid for a limited time and recertification is required after a number of years. Following are few demanding certifications [5, 29]:

- Microsoft Certified Solution Expert (MCSE): MCSE measures one's ability to build innovative software solutions across multiple technologies, both on-premises and in the cloud. This certification most probably replaces long-lasting Microsoft Certified System Engineer (MCSE). This newly revamped certification can be earned through eight paths based on eight server technologies that Microsoft markets. For each path, an individual has to pass five exams [17].

- Microsoft Certified Solutions Developer (MCSD): This certification validates one's ability to design and build software solutions that extend beyond traditional platform boundaries. The newly revamped MCSD certification has three tracks: Windows Store Apps, Web Applications, and Application Lifecycle Management. Each track requires an individual to pass five tests [17]. 
- Project Management Professional (PMP): Globally recognized and demanded, the PMP certification demonstrates that one has the experience, education and competency to lead and direct complex projects. One must have between three to five years of verifiable project management experience to take the exam, along with 35 hours of project management education and a degree [24].

- Cisco Certified Network Associate (CCNA): This vendor-specific certification authenticates an individual's ability to administer medium-size route and switched Cisco networks. To earn this certification, one can either pass the 640-802 CCNA exam or both the 640-822 ICND1 and 640-816 ICND2 exams. The CCNA designation is valid for three years, after which one must pass one of various possible exams for renewal [6].

- Oracle Certified Professional (OCP): This Oracle certification validates the skills and experience required to manage, develop, or implement enterprise-wide databases, middle-ware or applications [21]. This certificate is appropriate for mid to senior level Oracle database administrators. To achieve OCP, one has to complete the first exam, Oracle Certified Associate.

- A+: This CompTIA certification is designed for computer technicians and it covers topics such as hardware, Operating system, and networking. Six months of technician experience is recommended and two exams are required.

- Certified Information Systems Security Professional (CISSP): CISSPs are information assurance professionals who define the architecture, design, management and/or controls that assure the security of business environments. It is offered by the International Information Systems Security Certification Consortium $(\text { ISC) })^{2}$.

It should be clear that many demanding certifications require several exams or practical experience. Others can be easily integrated into junior college curriculum. Thus careful thoughts must be given before implementing any certification into traditional college or university degree curriculum, which can be clear from the following discussion.

\section{INTEGRATION INTO THE GRADUATE MIS CURRICULUM}

Over the past few years, several IT certifications were integrated into the graduate MIS curriculum at the University of Houston-Clear Lake. The integration was not a planned or coordinated effort of the faculty members of the department, but an individual faculty member's quest to implement Oracle certifications in his graduate-level database courses. Ultimately the particular faculty member pursued other faculty members to implement certification of their choice in their courses. Majority of the faculty members went along with the new initiative and few showed resentment. Nevertheless Microsoft, Cisco and Oracle certifications were implemented into programming, web development, networking and database courses. It was also suggested that certifications produced increased enrollment in the graduate MIS program, and it gave an edge in obtaining 17-month extension of OPT (Optional Practical Training) for the foreign graduate students, which is an important factor for the survival of many IT programs. Recently certification data from several courses are also used as a benchmark in the quality assurance process of AACSB for the MIS program.

As there was no overall planning to implement a specific certification for a specific course, the result was challenging for most faculty members. Some faculty members had to implement two certification exams in two different courses in one semester. One faculty member became overly enthusiastic to implement two certification exams in two different courses in two different semesters to complete a set of certification exams required to obtain a certificate. For example, to obtain Microsoft Certified Technology Specialist (MCTS) credential, one had to 
complete two exams: 70-505 and 70-536. After implementing this for a semester or two, the particular faculty member not only gave up the whole idea but completely got out of the courses that involved certification exams.

Certification exams required significant changes in course curriculum and teaching methodology. In most cases, certification materials hardly matched the course content. For example, there is no certification exam on Visual Basic or C\# programming from Microsoft, but on Visual Studio developmental tool that uses VB or C\# as a language. The biggest challenge was not to implement a particular certification in a particular course, but the changing nature of certification in almost every two years. As soon as a faculty member becomes knowledgeable and comfortable in integrating certification materials with the course content, the certification company overhauls the certification process and related exams. Old certification exams become obsolete and a whole new set of certification exams becomes available.

With a maze of certification paths and exams that change so frequently, it becomes impossible for a faculty member to implement a particular exam in his or her course and stay with it. Nevertheless, with all the challenges, the certifications opened new doors for faculty and students alike and its long-term result is yet to be seen. All the faculty members teaching a course that requires certification are certified themselves. However, it is not clear how students felt in general about the certification process and that is the purpose of this study as discussed in the following.

\section{RESEARCH METHODOLOGY}

Through informal discussions, we are aware how faculty members feel about certification; however, we do not know how students received this challenge. Did they find any value to it? Which certifications did they find to be most valuable? We also wanted to know whether certification played a role in graduate enrollment! Thus, we developed a survey instrument that was distributed to former and current students of MIS program. We have used online SurveyMonkey tool (www.surveymonkey.com) to collect data from a 10-question survey that can be found in Appendix A. About half of the questionnaire is addressed to an IT person in general and the rest is focused on past and present students of MIS program. The survey link was distributed through social media contacts like Facebook and e-mail. We have distributed the questionnaire to about 70 recipients, and 27 of them completed the survey - that is about $40 \%$ response rate. It is expected that most former students had several certifications and the new students may have some certification or no certification yet.

As there was no overall plan of implementing certifications as students go through the curriculum from semester to semester, we felt that the students were overwhelmed by the number of certifications and their implementation process. Some students had to take three certification exams at the end of one semester. At the beginning, the burden of preparing for the certification exams was left to the students. Also in most cases, the certification materials did not match well with the course materials. We thus hypothesized that students are not enthusiastic about the certification in general. Furthermore, based on our experience in teaching a certification-oriented course that is required by all students and taken by majority of our incoming students, we also hypothesized that most students did not know about certification program before joining the MIS program.

\section{RESULTS \& DISCUSSION}

In responding to question \#1, whether IT Certification can help build a better IT career, a significantly $96 \%$ agreed and merely $4 \%$ disagreed. In finding how many certifications one already has, it is found that 11 people hold 28 certifications in total - with an average of 2.5 certifications; and 16 people do not hold any certification yet. Presumably the latter are new students in their first semester. This is surprising contrary to our hypothesis that even new students have a positive view towards certification.

In finding which type IT certifications individuals are holding through responses from question \#3, again 11 answered and 16 skipped. The latter group again is most likely the new students; however, according to the answer of question \#1, almost all of them value certification. Table 1 shows various certifications held by the percentage of people. It can be seen that Oracle and Microsoft certifications are prevalent, followed by Cisco and Novell. We did not ask for specific certification name or exam in this question; however, we went into specifics in question \#5. 
In finding how many IT certification one should have through question \#4, 24 people answered and 3 skipped. Responses varied between 1 and 6, with an average of 2.9. Majority of the people says that one should have 2 or 3 certifications; however, several people suggested for even 5 certifications.

\begin{tabular}{|l|l|}
\hline \multicolumn{1}{|c|}{ Table 1: Percent of People Holding IT Certifications } & Percent \\
\hline Type of Certification & $64 \%$ \\
\hline Oracle (SQL Expert, PL/SQL Expert, OCA, OCP, etc.) & $55 \%$ \\
\hline Microsoft MCTS (70-505, 70-511, 70-515, 70-526, 70-536, 70-562, etc.) & $18 \%$ \\
\hline Cisco (CCENT, CCNA, CCNP, CCDA, etc.) & $18 \%$ \\
\hline Novell & $\begin{array}{l}\text { Other: SAP, IBM DB2, GIS, Scrum Master Certified, Salesforce ADM 201, ADM 401, Workday HCM } \\
\text { Certification, and MIS. Most probably these are obtained outside of the MIS curricular study. }\end{array}$ \\
\hline
\end{tabular}

In question $\# 5$, we asked specifically which IT certifications are mostly useful whether someone have them or not. People had to type the names of the certifications they felt mostly useful in the order of importance. Twenty-four people answered and 3 people skipped. However, about half of the respondents named the company and the rest named the certification. As shown in Table 2, Oracle, Microsoft, and Cisco topped the list with equal importance in the first choice. As majority of the respondents answered this question, it is clear that students who did not take any certification exam, had a positive view and knowledge about IT certifications.

\begin{tabular}{|l|l|}
\hline \multicolumn{2}{|c|}{ Table 2: Popular IT Certifications by the Number of Respondents } \\
\hline First Choice & No. of Respondents \\
\hline Oracle (SQL, PL/SQL, SQL Expert) & 8 \\
\hline Microsoft (MCSE, MCSD, MCTS, .NET, C\#) & 7 \\
\hline Cisco (CCNA) & 7 \\
\hline Other: ITIL, BW & 2 \\
\hline
\end{tabular}

Question \#6 was to find out whether the respondent is a former or current student of the MIS program. All 27 respondents answered that they are current or past students of MIS program. The follow-up question \#7 was to find whether the individual knew about IT certification program in the MIS department before joining the university. All 27 responded with $63 \%$ saying that they knew about IT certifications before joining the program and $37 \%$ did not. Obviously our hypothesis was somewhat wrong. May be some of the former students did not know about the IT certifications in the MIS department, but the majority of the incoming students knew. One possible reason might be that, the majority of our graduate students come from India, and there is a significant communication between the incoming and outgoing students. Furthermore, many of these students most probably come from a general geographical location of India, where they can have significant communication among themselves within educational and professional institutions.

Question \# 8 was to find out whether the MIS program prepared them as a better candidate for IT career. Of the 27 respondents, $78 \%$ says that they are prepared, $4 \%$ says no, and $18 \%$ says that they do not know. Note that even though this question was intended for the past MIS students, all choose to participate. The majority felt that they were prepared or being prepared well for the certification exams. Question \#9 was to find out the level of preparation provided by the MIS

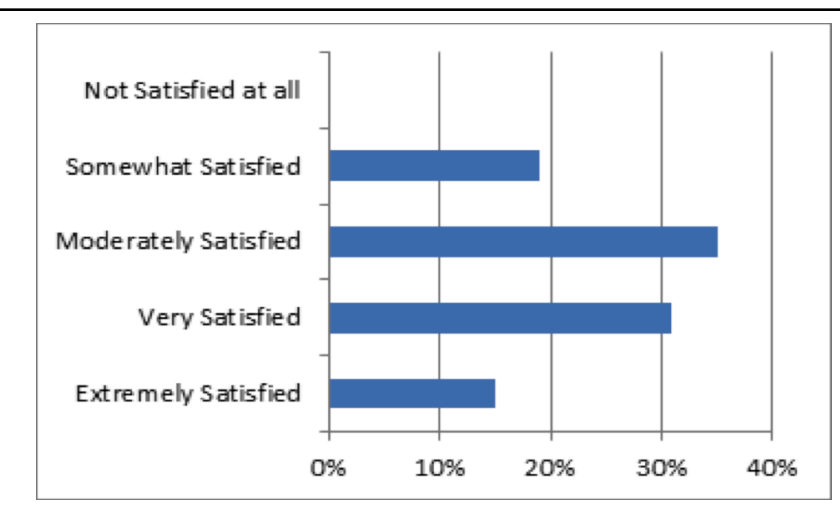

Figure 1: Student Satisfaction of Certification Preparation 


\section{Issues in Information Systems}

Volume 14, Issue 1, pp.153-161, 2013

program for the certification exams. Almost all responded and Figure 1 shows the result. It is seen that the majority of the students have been satisfied the way MIS program prepares them for the certification exams. That means that faculty members in general integrated, guided and taught certification materials in a satisfactory manner.

Few individuals responded to \#10 with some positive message or suggestions and did not show any negative viewpoints towards certification. Note that the survey was limited to 10 questions, because of the limitation of the free version of the SurveyMonkey tool. We also did not want to overburden the respondents with too many timeconsuming questions, resulting incomplete surveys. In the future, we wish to expand our study beyond our students.

\section{CONCLUSIONS}

We have discussed the value of IT certification which can boost a job candidate's chance of getting attention of a hiring manager in a competitive job market and where employers are looking for quality IT personnel. Educationists have been suggesting to implement IT certifications in the traditional university computing curricula; however, based on our literature search, there was no report of significant implementation. We have discussed how several IT certifications have been integrated into various core courses of the MIS program at our university. As instructors, we have gone through the complexity of integrating certification materials into the course materials. In most cases, certification materials did not match with the traditional course materials; rather they are based on tools and technologies of IT vendors. Furthermore, the changing nature of certifications in almost every two years has been a challenge for the faculty members. But it gave an opportunity to become knowledgeable about the IT certification in general and to be current with the in-depth knowledge of the technology of the IT industry. It brings a positive change to our traditional MIS program and makes our program closer to industry standards. We became confident about the marketability of our graduates.

However, we did not have a clear understanding how our students felt about the certification process within our program. We thus performed a survey on our past and present students to understand their perceived value towards certification. It is found that almost all current or past students believe that IT certification can help them build a better career. Certifications from Oracle, Microsoft and Cisco are found to be most valuable to them. Survey also shows that about two-thirds of the students knew about the certification program before joining the program. It also shows that the majority of the students have been satisfied the way our MIS program prepares them for the certification exams.

We can conclude that educationists who have faced with the dilemma of whether or not to adapt IT certifications in the computing curricula, should take the steps of integrating IT certifications in their curricula. It may not be a pleasant ride to start with, but once few hurdles are crossed, faculty members will find satisfaction through professional achievements and student success stories. It will also bring IT departments up to the par of IT industry standards.

\section{REFERENCES}

1. Al-Rawi, A., Bouslama, F., and Lansari, A. (2006), "Preparing Undergraduate Students for IT Certification," Issues in Informing Science \& Information Technology, Vol. 3, pp. 33-44.

2. Anderson, J. E., Barrett, K. and Schwager, P. H. (2005), "An Exploration of the Value of Information Systems Certification: The Perspective of the Human Resource Professional," Eighth Americas Conference on Information Systems, pp. 2134-2142.

3. Arora, R., "Tech-Know: The Value Of IT Certifications," http://ezinearticles.com/?Tech-Know:-The-Value-OfIT-Certifications\&id=6966706.

4. Bort, J. (2011), "Survey: IT Certifications Lead to Jobs, Higher Pay," NetworkWorld, http://www.networkworld.com/news/2011/111411-it-certifications-lead-to-higher-pay-252852.html.

5. Certification Magazine, “Certification Top 10 Lists,” http://www.certmag.com/read.php?in=487. 


\section{Issues in Information Systems}

Volume 14, Issue 1, pp.153-161, 2013

6. Cisco Learning Network, https://learningnetwork.cisco.com/community/certifications.

7. CompTIA, "State of the IT Skills Gap," http://www.wired.com/wiredenterprise/wpcontent/uploads/2012/03/Report - CompTIA IT Skills Gap study - Full Report.sflb .pdf

8. Gabelhouse, G. (2002), "Certification, Salaries \& the IT Market," Certification Magazine, www.certmag.com.

9. Frank, C. and Werner, L. (2010), "The benefit of the CSSLP certification for educators and professionals," Journal of Computing Sciences in Colleges, Volume 26 Issue 1, pp. 49-55.

10. GoCertify.com, http://www.gocertify.com/certifications/vendor-list.html.

11. Hitchcock, L. (2007), "Industry Certification and Academic Degrees: Complementary, or Poles Apart?" SIGMIS-CPR'07, ACM, pp. 95-100.

12. Hunsinger, D. S. and Smith, M. A. (2005), "Predicting Hiring Managers' Intentions to use I.T. Certification in the Selection Process," Journal of Information Technology Management, Volume XVI, Number 4, pp. 1-18.

13. Hunsinger, D. S. and Smith, M. A. (2008), "Factors that Influence Information Systems Undergraduates to Pursue IT Certification," Journal of Information Technology Education, Volume 7, pp. 247-265.

14. Jovanovic, R., Bentley, J., Stein, A., and Nikakis, C. (2006), "Implementing Industry Certification in an IS curriculum: An Australian Experience," Information Systems Education Journal, Volume 4, Number 59, pp. 18.

15. Lee, S. M. and Lee, C. K. (2006), "IT Managers' Requisite Skills," Communications of the ACM, Vol. 49, No. 4, pp.111-114.

16. Messmer, E. (2012), "US Army finds IT Security Certification Difficulties," NetworkWorld, http://www.networkworld.com/news/2012/041012-army-security-certs-258136.html, April.

17. Microsoft Certification Overview, http://www.microsoft.com/learning/en/us/certification-overview.aspx.

18. Microsoft Certified Professional Magazine, http://mcpmag.com/Articles/2011/04/14/2011-SalarySurvey.aspx ?Page $=7 \#$ certimpact.

19. Microsoft Learning, "Certification benefits," http://www.microsoft.com/learning/en/us/certificationbenefits.aspx\#fbid=s4-7we9VOuM

20. Nelson, M. L. and Rice, D. (2001), "Integrating third-Party Certification with Traditional Computer Education," Journal of Computing Sciences in Colleges, Volume 17, Issue 2, pp. 280-287.

21. Oracle Certification Program, http://en.wikipedia.org/wiki/Oracle_Certification_Program.

22. Ortiz, A. (2003), "Preparing Undergraduate Students for Java Certification," Proceeding OOPSLA '03 Companion of the 18th annual ACM SIGPLAN conference on Object-oriented programming, systems, languages, and applications, pp. 178-183.

23. Prabhakar, B., Litecky C. R. and Arnett, K. (2005), "IT skills in a tough job market," Communications of the $A C M$, Volume 48, Issue 10, pp. $91-94$.

24. Project Management Professional, http://www.pmi.org/Certification/Project-Management-ProfessionalPMP.aspx.

25. Randall, M. H. and Zirkle, Christopher J. (2005), "Information Technology Student-Based Certification in Formal Education Settings: Who Benefits and What Is Needed," Journal of Information Technology Education, Volume 4, p. p287-306.

26. Robin, G. (2011). "Do companies Look for Education, Certifications or Experience: A Quantitative Analysis," Proceedings of the 49th SIGMIS Annual Conference on Computer Personnel Research, pp. 1-5.

27. Schlichting, C. and Mason, J. (2004), "Certification Training and Academy," Journal of Computing Sciences in Colleges, Volume 20, Issue 1, pp. 157-167.

28. Schlichting, C. and Mason, J. (2005), "The computer curriculum and certification: a proposal," Journal of Computing in Small Colleges, Volume 20, Issue 4, pp. 84-91.

29. Schneider, L., "Top 15 Highest Paying Certifications in the Technology Industry," http://jobsearchtech.about.com/od/educationfortechcareers/tp/HighestCerts.htm.

30. Wireschen, D. and Zhang, G. (2010), "Information Technology Certification Value: An Initial Response from Employers," Journal of International Technology and Information Management, Vol. 19, No. 4, pp. 89-108. 


\section{Appendix: A}

\section{IT Certification Survey}

This Survey is to obtain your honest opinion about IT certification, if you had any. This is an anonymous survey and it will be used only for research purpose. Your response will be highly appreciated.

\section{Please answer the following as they apply to you:}

\begin{tabular}{|c|l|l|l|}
\hline 1 & Do you believe that IT certification can help you build a better IT career? & $\square$ Yes & $\square$ No \\
\hline 2 & How many IT Certifications do you have so far? & Number: \\
\hline 3 & $\begin{array}{c}\text { Please check the companies that provided your IT certifications? } \\
\text { Microsoft: } \square \quad \text { Oracle: } \square \quad \text { Cisco: } \square \quad \text { Novell: } \square \quad \text { Other (Type): }\end{array}$ & \begin{tabular}{c} 
Number: \\
\hline 4
\end{tabular} & $\begin{array}{c}\text { In your opinion, how many IT Certifications one should have? } \\
\text { In your opinion which IT certifications are mostly useful whether you have them or not? } \\
2:\end{array}$ \\
\hline 5
\end{tabular}

The Following questions are for Current or Former Students of MIS Program at UHCL ONLY

\begin{tabular}{|l|l|l|l|}
\hline 6 & Are you a current or former student of MIS program at UHCL? & $\square$ Yes \\
\hline 7 & Did you know about IT Certifications in the MIS program before joining UHCL? & $\square$ Yes $\square$ No \\
\hline 8 & $\begin{array}{r}\text { Do you believe that IT certifications in the MIS program prepared you as a better candidate for IT career? } \\
\text { Yes: } \square \quad \text { No: } \square \quad \text { Not Sure: } \square\end{array}$ \\
\hline 9 & $\begin{array}{c}\text { Overall how satisfied are you about the IT Certification preparation provided by the MIS program? } \\
\text { Very Satisfied: } \square \quad \text { Noderately Satisfied: } \square\end{array}$ \\
\hline 10 & $\begin{array}{l}\text { Additional Comments \& Suggestions: } \\
\end{array}$ & \\
\hline
\end{tabular}

